\title{
Apnéia na Sala de Recuperação Pós-Anestésica. Relato de Caso *
}

\section{Apnea in the Postanesthetic Recovery Room. Case Report}

\author{
Joel Massari Rezende, TSA $^{1}$
}

\begin{abstract}
RESUMO
Rezende JM - Apnéia na Sala de Recuperação Pós-Anestésica. Relato de Caso

JUSTIFICATIVA E OBJETIVOS: A depressão respiratória é uma complicação que pode ocorrer no pós-operatório quando se utilizam opióides na anestesia. O objetivo deste relato é discutir um caso de apnéia em paciente que chegou consciente à sala de recuperação pós-anestésica (SRPA), após ter sido submetido à tireoidectomia sob anestesia geral com propofol, fentanil e isoflurano.
\end{abstract}

RELATO DO CASO: Paciente do sexo feminino, 50 anos, 60 $\mathrm{kg}$, estado físico ASA l, submetida à tireoidectomia sob anestesia geral induzida com propofol (140 mg), fentanil (350 $\mu \mathrm{g}$ ), atracúrio $(30 \mathrm{mg})$ e mantida com isoflurano, duas doses subseqüentes em bolus de atracúrio (10 mg cada) e ventilação controlada mecânica. No final da cirurgia, após antagonização do bloqueio neuromuscular, a paciente foi extubada, obedeceu aos comandos para respirar e colaborou na passagem à maca, sendo transportada para a SRPA, aonde chegou consciente. Minutos após, apresentou apnéia, cianose e inconsciência. Foi realizada ventilação manual com oxigênio a $100 \%$ seguida de injeção de naloxona $(0,2 \mathrm{mg})$ por via venosa, havendo retorno da ventilação espontânea e da consciência.

CONCLUSÕES: Os cuidados ventilatórios no pós-operatório, durante o transporte, admissão à SRPA e permanência nessa unidade, devem ser contínuos em pacientes que receberam opióides, mesmo demonstrando estar conscientes ao deixarem a sala cirúrgica.

Unitermos: COMPLICAÇÕES: apnéia, hipóxia

\author{
SUMMARY \\ Rezende JM - Apnea in the Postanesthetic Recovery Room. \\ Case Report
}

BACKGROUND AND OBJECTIVES: Respiratory depression is a postoperative complication which may occur when opioids are employed in anesthesia. This report aimed at discussing a case of apnea in a conscious patient admitted to the post anesthetic recovery room, after thyroidectomy under general anesthesia with propofol, fentanyl and isoflurane.

CASE REPORT: Female patient, 50 years old, $60 \mathrm{~kg}$, physical status ASA I, submitted to thyroidectomy under general anesthesia induced with propofol $(140 \mathrm{mg})$, fentanyl $(350 \mu \mathrm{g})$ and atracurium (30 mg), and maintained with isoflurane, two subsequent atracurium boluses (10 $\mathrm{mg}$ each) and mechanically controlled ventilation. At surgery completion and after neuromuscular block recovery, patient was extubated, responded to breathing commands and cooperated during transfer to the stretcher, being taken to the PACU, where she arrived fully conscious. Minutes after, she was apneic, cyanotic and unresponsive. Manual ventilation was installed with $100 \%$ oxygen, followed by intravenous naloxone $(0,2 \mathrm{mg})$ and patient recovered spontaneous breathing and consciousness.

CONCLUSIONS: Respiratory care in the postoperative period, during transportation, PACU admission and stay should be continuous in patients receiving opioids, even when they seem fully conscious in leaving the operating room.

Key Words: COMPLICATIONS: apnea, hypoxia

\section{INTRODUÇÃO}

É freqüente a observação de que pacientes sob efeito de opióides são capazes de respirar quando estimulados a fazê-lo, mesmo quando a dose do opióide é suficiente para causar apnéia.

No final da anestesia, a ação dos hipnóticos como o propofol, e de halogenados, pode regredir rapidamente, permitindo

\footnotetext{
* Recebido do (Received from) Hospital do Servidor Público Estadual de São Paulo, SP

1. Membro do CET do Hospital do Servidor Público Estadual de São Paulo "Francisco Morato de Oliveira"; Responsável pelo CET Dr. Luiz Gustavo F. Victoria
}

Endereço para correspondência (Correspondence to) Dr. Joel Massari Rezende

Av. Conselheiro Rodrigues Alves, $n^{\circ}$ 999/71, Vila Mariana 04014-012 São Paulo, SP

Apresentado (Submitted) em 20 de junho de 2002

Aceito (Accepted) para publicação em 05 de novembro de 2002

(C) Sociedade Brasileira de Anestesiologia, 2003

Revista Brasileira de Anestesiologia

Vol. 53, № 3, Maio - Junho, 2003 que o paciente recupere a consciência, ainda que mantendo uma concentração plasmática de opióide suficiente para provocar apnéia. Nesta situação, a apnéia estará presente se não houver estímulo verbal para que o paciente respire. Existem relatos de apnéia na sala de recuperação pós-anestésica (SRPA) em pacientes que foram transportados até a mesma, conversando e respondendo a ordens simples, num estado aparentemente normal ${ }^{1-3}$.

O objetivo deste relato é mostrar um caso de apnéia em paciente que chegou consciente à SRPA, após ter sido submetida à tireoidectomia sob anestesia geral com propofol, fentanil e isoflurano.

\section{RELATO DO CASO}

Paciente de sexo feminino, 50 anos, $65 \mathrm{~kg}$ de peso, a ser submetida à tireoidectomia total por bócio adenomatoso difuso, com múltiplos nódulos bilaterais. Apresentava PA, FC e ECG de repouso e ecodopplercardiografia dentro da normalidade; hemograma, eletrólitos, glicemia de jejum, uréia, creatinina e provas de coagulação normais; T-3 = 161 (normal entre 80 e 220); T-4 = 8,8 (normal entre 4,5 e 12); TSH = 0,3 (nor- 
mal entre 0,3 e 4). Foi feita medicação pré-anestésica com midazolam ( $5 \mathrm{mg}$ ) por via muscular, às $7 \mathrm{~h} 45$ minutos. Aanestesia foi iniciada com propofol (140 mg), fentanil $(350 \mu \mathrm{g}) \mathrm{e}$ atracúrio (30 mg iniciais, e mais duas doses subseqüentes de $10 \mathrm{mg}, 60$ e 105 minutos após). Foi feita intubação traqueal com tubo de $8 \mathrm{~mm}$, com balonete, e a manutenção com isoflurano em concentrações entre $1 \%$ e $2 \%$, em mistura de $\mathrm{O}_{2}$ $\left(1 \mathrm{~L} \cdot \mathrm{min}^{-1}\right.$ ) e $\mathrm{N}_{2} \mathrm{O}$ ( 1 L. $\mathrm{min}^{-1}$ ) em ventilação mecânica com sistema semi-fechado : $\mathrm{VC}=700 \mathrm{ml} ; \mathrm{FR}=10 / \mathrm{min}$. A monitorização constou de cardioscópio, oxímetro e PANI. Foi feita tireoidectomia total, sendo comprovado bócio colóide multinodular. Após a cirurgia, foi feita reversão do bloqueador neuromuscular com neostigmina $(1,5 \mathrm{mg})$, precedida por atropina $(0,75 \mathrm{mg})$. A paciente foi mantida em ventilação mecânica com $\mathrm{O}_{2}$ a $100 \%$, até abrir os olhos, sendo então extubada. Respirou após a extubação, conforme solicitado, ajudou na passagem à maca, e foi transportada à SRPA, aonde chegou consciente, sendo monitorizada com oxímetro, cardioscópio e PANI, e mantida sob máscara facial de $\mathrm{O}_{2}$. Após alguns minutos, a enfermagem, alertada pela diminuição da $\mathrm{SpO}_{2}$, constatou apnéia, cianose e inconsciência. Chamado às pressas, o anestesiologista realizou ventilação manual com $\mathrm{O}_{2}$ a $100 \%$, por máscara-balão, e administrou em seguida 0,2 mg de naloxona, por via venosa. A paciente recuperou imediatamente a coloração normal, a consciência, evoluindo sem qualquer anormalidade.

\section{DISCUSSÃO}

Encontramos na literatura três outros relatos de depressão respiratória inesperada na SRPA, em pacientes que deixaram a SO inteiramente despertos, após anestesia geral, apresentando semelhanças com o presente relato ${ }^{1-3}$.

Nos três casos relatados, o opióide utilizado foi sufentanil; os pacientes eram adultos jovens submetidos à cirurgia de médio porte, com duração média de 150 minutos ${ }^{1-3}$.

Os aspectos clínicos do nosso caso e dos relatos apresentados sugerem a ocorrência de depressão respiratória associada ao opióide, cujos efeitos farmacológicos foram mais prolongados que os dos outros medicamentos usados na anestesia.

A farmacocinética dos opióides e do propofol - medicamentos habitualmente usados em associação - é descrita atualmente por um modelo tricompartimental. O medicamento injetado em bolus no sangue distribui-se rapidamente aos tecidos altamente perfundidos (coração, fígado, rins, cérebro e pulmões) e mais lentamente aos outros tecidos: músculos, intestinos, pele e gordura. Em uma terceira fase, inverte-se o sentido da distribuição e passa a predominar a eliminação da droga do organismo.

A partir da curva de concentração plasmática pode-se definir uma meia-vida de distribuição rápida, uma meia-vida de distribuição lenta, e uma meia-vida terminal, ou meia-vida de eliminação - esta era a única considerada nas publicações antigas. As meias-vidas representam o tempo para que a concentração plasmática da droga seja reduzida à metade ${ }^{4,5}$.

As meias vidas (terminais) dos opióides mais comumente utilizados são: fentanil (2 - $4 \mathrm{~h})$; sufentanil (2 - $3 \mathrm{~h}$ ); alfentanil (1 $2 \mathrm{~h})$; remifentanil $(0,1-0,6 \mathrm{~h})$; morfina $(1,7-2,2 \mathrm{~h})$ e meperidina $(3-5 h)^{6}$.

Como a meia-vida terminal desconsidera as fases em que predominam as distribuições rápida e lenta, na prática ela é maior que o tempo necessário para a diminuição da concentração plasmática à metade, após um bolus ou uma infusão; quanto mais longa a infusão, mais esse tempo aproxima-se da meia-vida terminal ${ }^{7}$. Considerando infusões de durações variadas, Hughes ${ }^{8,9}$ estudou os tempos necessários para que a concentração plasmática decaísse a $50 \%$, após infusão mantenedora de concentração plasmática constante, designando-os pelo termo "meia-vida contexto-dependente" - a palavra "contexto" aplicando-se à duração da infusão.

Em princípio, drogas com meia-vida (terminal) mais longa, e infusões mais prolongadas (isto é: maiores meias-vidas contexto-dependente) tendem a apresentar efeitos mais duradouros, mas não existe uma relação simples entre meia-vida e duração do efeito, pois esta também depende da dose utilizada. A dose é calculada tendo em vista a chamada "janela terapêutica", isto é: a faixa de concentrações plasmáticas em que a droga exerceria seus efeitos desejáveis. Acima dessa "janela terapêutica", os efeitos nocivos são excessivos; abaixo, os efeitos desejados tendem a desaparecer. No caso do propofol, abaixo da janela terapêutica, há o retorno da consciência; no caso dos opióides, há redução da ação analgésica, bem como das ações indesejáveis que a acompanham, como a depressão respiratória.

No caso dos opióides de meia-vida longa, é necessário titular com cuidado a dose, para não haver efeitos prolongados além do desejável.

Na prática, utilizamos nosso julgamento clínico para que no pós-operatório imediato o paciente esteja sob o efeito da ação analgésica residual do opióide (na maioria das vezes), e que a depressão respiratória, que a acompanha, seja suficientemente moderada para evitar retenção importante de $\mathrm{CO}_{2}$, e permitir boa saturação arterial mediante oferta de oxigênio por máscara ou cateter nasal.

Há trabalhos ${ }^{10,11}$ demonstrando que o uso da técnica de infusão contínua permite obter uma anestesia mais estável que pelo método de bolus repetidos; apresentam tabelas obtidas a partir de estudos em computador, para facilitar ao anestesiologista o cálculo das velocidades de infusão de opióides e propofol, conforme o peso do paciente e o tipo de cirurgia. Recomendam a interrupção da infusão do opióide 20 a 30 minutos antes do momento desejado para a recuperação. Outro estudo ${ }^{12}$ sugere o uso do remifentanil em infusão contínua de $0,5 \mu \mathrm{g} \cdot \mathrm{kg}^{-1} \cdot \mathrm{min}^{-1}$, após um bolus inicial de $1 \mu \mathrm{g} \cdot \mathrm{kg}^{-1}$, com associação de hipnótico. Por ser metabolizado por esterases inespecíficas do sangue, permite a ventilação espontânea em até 7 minutos, após a interrupção da infusão. No final da anestesia, a ação do propofol (e/ou do halogenado) pode regredir mais rapidamente que a do opióide, permitindo que o paciente recupere a consciência, ainda que man- 
tendo uma concentração plasmática do opióide suficiente para provocar apnéia. Se solicitarmos ao paciente que respire, ele poderá fazê-lo, assim como obedecerá a outras ordens simples. Se deixarmos de estimulá-lo, ele "esquecer-se-á" de respirar (fenômeno chamado de "oubli respiratoire" pelos autores franceses) ${ }^{13}$. Isto explicaria a apnéia súbita que ocorre na SRPAcom alguns desses pacientes. Outra explicação apresentada ${ }^{1}$ é a de que o opióide armazenado no tecido muscular tenda a passar ao plasma, em conseqüência do aumento da perfusão, causado pela volta do tônus, dos movimentos voluntários e da elevação da temperatura corporal.

Como a apnéia pode ocorrer em poucos minutos, é importante acompanhar o paciente à SRPA, verificando a colocação da máscara de oxigênio e do oxímetro de pulso, o qual, apesar das suas limitações, fornece a indicação mais precoce e importante da hipoxemia ${ }^{14}$; transmitir instruções ao pessoal de enfermagem e assegurar-se da sua cooperação, enfatizando a necessidade de observar cuidadosamente os movimentos ventilatórios do paciente. O paciente deve ser observado atentamente até que mantenha $\mathrm{SpO}_{2}$ adequada, sem a necessidade de estimulo para respirar. Como há uma grande variabilidade individual na resposta aos opióides, o uso de antagonista (naloxona), ou de agonista-antagonista (nalbufina) deve ser avaliado caso a caso ${ }^{15-25}$. Quando se decidir pelo seu emprego, o esquema de doses fracionadas de naloxona ou nalbufina, conforme proposto por Bailey ${ }^{24}$, parece adequado e seguro. O uso do antagonista não exime o anestesiologista dos cuidados com o paciente, mas inegavelmente amplia a margem de segurança. No entanto, tem como desvantagem a necessidade de complementação da analgesia.

Apesar de o caso ser simples, entendemos que sua apresentação servirá mais uma vez de alerta para o fato de que os cuidados ventilatórios durante o transporte, especialmente em longas distâncias, e na SRPA, devem ser contínuos em pacientes que receberam opióides, mesmo estando conscientes.

\section{Apnea in the Postanesthetic Recovery Room. Case Report}

Joel Massari Rezende, TSA, M.D.

\section{INTRODUCTION}

It is common to see patients under opioids being able to breathe when stimulated to do it, even when the opioid dose is high enough to cause apnea.

At the end of anesthesia, the action of hypnotics such as propofol, and halogenates, may be promptly reversed, allowing patient to recover consciousness although with a plasma opioid concentration high enough to cause apnea. In this situation, there will be apnea if patient is not verbally stimulated to breathe. There are reports on PACU apnea in patients who were transferred talking and responding to simple commands, in a seemingly normal state ${ }^{1-3}$.

This report aimed at describing a case of apnea in a patient arriving conscious to the PACU after being submitted to thyroidectomy under general anesthesia with propofol, fentanyl and isoflurane.

\section{CASE REPORT}

Female patient, 50 years old, $65 \mathrm{~kg}$, to be submitted to total thyroidectomy for diffuse adenomatous goiter. Patient had normal BP, HR and ECG at rest, and echodopplercardiography; blood count, electrolytes, fast glycemia, urea, creatinine and coagulation tests were also normal; T-3 = 161 (normal between 80 and 220); T-4 = 8.8 (normal between 4.5 and 12); $\mathrm{TSH}=0.3$ (normal between 0.3 and 4). Patient was premedicated with muscular midazolam $(5 \mathrm{mg})$ at 7:45 a.m. Anesthesia was induced with propofol (140 mg), fentanyl $(350 \mu \mathrm{g})$ and atracurium $(30 \mathrm{mg})$ followed by two subsequent $10 \mathrm{mg}$ doses, 60 and 105 minutes after). Patient was intubated with an $8 \mathrm{~mm}$ cuffed tube and anesthesia was maintained with isoflurane in concentrations between $1 \%$ and $2 \%$ in a mixture of $\mathrm{O}_{2}\left(1 \mathrm{~L} \cdot \mathrm{min}^{-1}\right)$ and $\mathrm{N}_{2} \mathrm{O}\left(1 \mathrm{~L} \cdot \mathrm{min}^{-1}\right)$ in a semi-closed mechanical ventilation system: $\mathrm{TV}=700 \mathrm{ml}$; RR $=10 / \mathrm{min}$. Monitoring consisted of cardioscopy, pulse oximetry and non invasive blood pressure. Total thyroidectomy was performed and a colloid multinode goiter was confirmed. After surgery, neuromuscular blocker was reverted with neostigmine $(1.5 \mathrm{mg})$, preceded by atropine $(0.75$ $\mathrm{mg}$ ). Patient was maintained under mechanical ventilation with $100 \%$ oxygen until opening her eyes, when she was extubated. Patient breathed after extubation as requested, cooperating during transfer to the stretcher and was transported to PACU where she arrived conscious and was monitored with pulse oximetry, cardioscopy and non-invasive blood pressure, being maintained under $\mathrm{O}_{2}$ facial mask. Some minutes later the nursing team, alerted by the decrease in $\mathrm{SpO}_{2}$, has detected apnea, cyanosis and unconsciousness. Called in a hurry, the anesthesiologist applied manual ventilation with $100 \% \mathrm{O}_{2}$ by a ventilation bag and facial mask and injected $0.2 \mathrm{mg}$ intravenous naloxone. Patient promptly recovered normal color and consciousness, evolving without any abnormality.

\section{DISCUSSION}

We have found in the literature three reports on unexpected respiratory depression in the PACU, in patients leaving the OR totally awaken after general anesthesia, and which were similar to our report ${ }^{1-3}$.

Sufentanil was used in all cases: patients were young adults submitted to mid-size surgeries with mean duration of 150 minutes ${ }^{1-3}$.

The clinical aspects of all cases, including ours, suggest respiratory depression associated to opioids, the effects of 
which were more prolonged than of the other drugs used in anesthesia.

Pharmacokinetics of opioids and propofol - drugs commonly used in association - is currently described by a three-compartment model. Bolus drug injected in the blood is promptly spread to highly perfused tissues (heart, liver, kidneys, brain and lungs), and more slowly to other tissues: muscles, guts, skin and fat. In a third stage, spread direction is reverted and drug excretion starts to predominate.

From plasma concentration curve it is possible to define a fast distribution half-life, a slow distribution half-life and a terminal half-life or elimination half-life - this was the only one taken into consideration in old publications. Half-life is the time for drug plasma concentration to be cut in half ${ }^{4,5}$.

More common opioid terminal half-lives are: fentanyl (2-4 h), sufentanil (2-3 h), alfentanil (1-2 h), remifentanil (0.1-0.6 h), morphine (1.7-2.2 h) and meperidine (3-5 h) ${ }^{6}$.

Since terminal half-life ignores stages where prompt and slow distributions predominate, in practice it is longer than the time needed for plasma concentration decrease to half after bolus or infusion; the longer the infusion, the closer this time gets to terminal half-life ${ }^{7}$. Considering infusions with different durations, Hughes ${ }^{8,9}$ has studied the times needed for plasma concentration decrease to $50 \%$ after infusion maintaining constant plasma concentrations and has named those times "context-sensitive half-time" - being "context" related to infusion duration.

In theory, longer (terminal) half-life drugs and more prolonged infusions (that is, longer context-sensitive half-time) tend to show more long-lasting effects, but there is no direct relationship between half-life and effect duration, because it also depends on the dose used. The dose is calculated according to the therapeutic range, that is, plasma concentration range in which the drug would have desirable effects. Above this therapeutic range, adverse effects are excessive; below, desirable effects tend to disappear. For propofol, below the therapeutic range there is a return to consciousness; for opioids there is analgesic action decrease as well as its undesirable effects, such as respiratory depression.

For long half-life opioids it is necessary to carefully titrate the dose to prevent prolonged effects beyond desirable.

In practice, our clinical judgment is used so that patients are under postoperative residual opioid analgesic action (most of the times) and that respiratory depression is moderate enough to avoid major $\mathrm{CO}_{2}$ retention and allow good arterial saturation through oxygen under mask or nasal catheter.

There are studies ${ }^{10,11}$ showing that the continuous infusion technique provides a smoother anesthesia as compared to repeated boluses; they present tables obtained by computer studies to help the anesthesiologist in calculating opioids and propofol infusion rates according to patients' weight and type of surgery. They recommend opioid infusion withdrawal 20 to 30 minutes before anticipated recovery time. A different study ${ }^{12}$ suggests $0.5 \mu \mathrm{g} \cdot \mathrm{kg}^{-1} \cdot \mathrm{min}^{-1}$ remifentanil continuous infusion after an initial $1 \mu \mathrm{g} . \mathrm{kg}^{-1}$ bolus and the association of hypnotics. For being metabolized by blood nonspecific stearases, it allows for spontaneous ventilation in up to $7 \mathrm{~min}$ utes after infusion withdrawal.

At the end of anesthesia, propofol (and/or halogenate) action may regress more promptly than that of opioids allowing the patient to recover consciousness although still with an opioid plasma high concentration enough to cause apnea. If patients are asked to breathe, they may do it as well as responding to other simple commands. If they are not stimulated, they will "forget" to breathe (phenomenon called "oubli respiratoire" by French authors) ${ }^{13}$. This would explain sudden PACU apnea in some patients. Another explanation ${ }^{1}$ would be that opioids stored in the muscles tend to cross to plasma as a consequence of increased perfusion caused by tone recovery, voluntary movements and body temperature increase.

Since apnea may develop in a few minutes, it is important to follow patients to the PACU, check the installation of oxygen mask and pulse oximetry which, in spite of its limitations, gives earlier and important hypoxemia indications ${ }^{14}$; give instructions to the nursing team and be sure of their cooperation, emphasizing the need for carefully observing patients' ventilatory movements. Patients should be closely observed until reaching adequate $\mathrm{SpO}_{2}$ with no need for breathing stimulations. Since there are major differences in individual responses to opioids, the use of antagonists (naloxone) or agonist-antagonists (nalbufine) should be evaluated in a case-by-case basis ${ }^{15-25}$. When deciding for their use, the scheme of fractional naloxone or nalbufine doses proposed by Bailey ${ }^{24}$ seems to be adequate and safe. The use of antagonists does not free the anesthesiologist from taking care of patients, but undoubtedly increases safety margin. However, the disadvantage is the need for analgesic complementation. Although being a simple case, we understand that its presentation will once more act as a caveat that ventilatory care during transportation, especially in long distances, and in the PACU should be continuous in patients receiving opioids, even when they are conscious.

\section{REFERÊNCIAS - REFERENCES}

01. Robinson D - Respiratory arrest after recovery from anaesthesia supplemented with sufentanil. Can J Anaesth, 1988;35:101-102.

02. Goldberg M, Ishak S, Garcia C et al - Post-operative rigidity following sufentanil administration. Anesthesiology, 1985;63: 199-201.

03. Chang J, Fish KJ - Acute respiratory arrest and rigidity after anesthesia with sufentanil: a case report. Anesthesiology, 1985;63:710-711.

04. Fernandes F, Issa E - Princípios Farmacológicos em Anestesia, em: Yamashita AM, Takaoka F, Auler Jr JOC et al Anestesiologia SAESP. $5^{\mathrm{a}}$ Ed, Rio de Janeiro, Atheneu, 2001; 351-364.

05. Youngs EJ, Shafer SL - Princípios Farmacocinéticos e Farmacodinâmicos Básicos, em: White PF - Tratado de Anestesia Venosa, Porto Alegre, Artmed Editora, 2001;27-41. 
06. Bailey P, Egan T - Fentanil e Congêneres, em: White PF Tratado de Anestesia Venosa, Porto Alegre, Artmed Editora, 2001;216-247.

07. Parsloe CP - Anestesia Intravenosa por Infusão AlvoControlada: O Que Aconteceu no Último Ano?, em: Atualização em Anestesiologia, Ed. São Paulo, 2000;5:94-102.

08. Hughes MA, Glass PSA, Jacobs JR et al - Context sensitive half time in multicompartiment pharmacokinetic models for intravenous anesthetic drugs. Anesthesiology, 1992;76:334-341.

09. White PF - Propofol, em: White PF - Tratado de Anestesia Venosa, Porto Alegre, Artmed Editora, 2001:121-160.

10. Vuyk J, Mertens MJ, Martin J et al - Propofol anesthesia and rational opioid selection: determination of optimal EC50-EC95 propofol-opioid concentrations that assure adequate anesthesia and a rapid return of consciousness. Anesthesiology, 1997;87:1549-1562.

11. Vianna PTG - Anestesia Venosa - Técnica e Indicações, em: Yamashita AM, Takaoka F, Auler Jr JOC et al - Anestesiologia SAESP, 5a Ed, São Paulo, Editora Atheneu, 2001;539-549.

12. Viana PTG - Novos Opióides e Opções de Uso, em: Atualização em Anestesiologia, São Paulo, 2000;5:72-83.

13. Leitão FBP - A neuroleptanalgesia tipo II na cirurgia da surdez. Rev Bras Anestesiol, 1966;16:412-433.

14. Fortis EAF, Nora FS - Hipoxemia e hipóxia per-operatória: conceito, diagnóstico, mecanismos, causas e fluxograma de atendimento. Rev Bras Anestesiol, 2000;50:317-329.

15. Bowdle TA - Opioid antagonists and agonist-antagonist combinations. ASA Annual Refresher Course Lectures, 1990;125:1-6.

16. Hatheway JA - Opióides, em: Duke J, Rosenberg SG - Segredos em Anestesiologia, $1^{\text {a }} \mathrm{Ed}$, Porto Alegre, Artes Médicas, 1997;94-101.

17. Gozzani JL - Opióides e antagonistas. Rev Bras Anestesiol, 1994;44:65-73.

18. Flacke JW, Flacke WE, Williams GD - Acute pulmonary edema following naloxone reversal of high-dose morphine anesthesia. Anesthesiology, 1997;47:376-378.

19. Azar I, Turndorf H - Severe hypertension and multiple atrial premature contractions following naloxone administration. Anesth Analg, 1979;58:524-525.

20. Estilo AE, Cotrell JE - Naloxone, hypertension, and ruptured cerebral aneurysm. Anesthesiology, 1981;54:352.

21. Andree RA - Sudden death following naloxone administration. Anesth Analg, 1980;59:782-784.
22. Prough DS, Roy R, Bumgarner $\mathrm{J}$ et al - Acute pulmonary edema in healthy teenagers following conservative doses of intravenous naloxone. Anesthesiology, 1984;60:485-486.

23. Moldenhauer CC, Roach GW, Finlayson DC et al - Nalbuphine antagonism of ventilatory depression following high doses fentanyl anesthesia. Anesthesiology, 1985;62:647-650.

24. Bailey PL, Clark NJ, Pace NL et al - Antagonism of postoperative opioid-induced respiratory depression: nalbuphine versus naloxone. Anesth Analg, 1987;66:1109-1114.

25. Latasch L, Probst S, Dudziak R - Reversal by nalbuphine of respiratory depression caused by fentanyl. Anesth Analg, 1984;63:814-816.

\section{RESUMEN}

Rezende JM - Apnea en la Sala de Recuperación Pós-Anestésica. Relato de Caso

JUSTIFICATIVA Y OBJETIVOS: La depresión respiratoria es una complicación que puede ocurrir en el pós-operatorio cuando se utilizan opioides en la anestesia. El objetivo de este relato es discutir un caso de apnea en paciente que llegó consciente a la sala de recuperación pós-anestésica (SRPA), después de haber sido sometido a tireoidectomia sobre anestesia general con propofol, fentanil e isoflurano.

RELATO DE CASO: Paciente del sexo femenino, 50 años, 60 $\mathrm{kg}$, estado físico ASA I, sometida a la tireoidectomia sobre anestesia general inducida con propofol (140 mg), fentanil (350 $\mu \mathrm{g})$, atracúrio (30 $\mathrm{mg})$ y mantenida con isoflurano, dos dosis subsecuentes en bolus de atracúrio (10 mg cada) y ventilación controlada mecánica. En el final de la cirugía, después de antagonización del bloqueo neuromuscular, la paciente fue extubada, obedeció a los comandos para respirar y colaboró en el pasaje a la maca, siendo transportada para la SRPA, donde llegó consciente. Minutos después presentó apnea, cianosis e inconsciencia. Fue realizada ventilación manual con oxígeno a $100 \%$ seguida de inyección de naloxona $(0,2 \mathrm{mg})$ por vía venosa, habiendo retorno de la ventilación espontanea y de la consciencia.

CONCLUSIONES: Los cuidados ventilatorios en el pós-operatorio, durante el transporte, admisión a la SRPA, y permanencia en esa unidad, deben ser continuos en pacientes que recibieron opioides, mismo demostrando estar conscientes al dejar la sala quirúrgica. 